\title{
Concentrations and isotopic characteristics of atmospheric reactive nitrogen around typical sources in Beijing, China
}

\author{
LIU Jieyun ${ }^{1,2,3}$, ZHANG Ying ${ }^{1}$, LIU Xuejun ${ }^{1 *}$, TANG Aohan ${ }^{1}$, QIU Husen ${ }^{3}$, ZHANG Fusuo ${ }^{1}$ \\ ${ }^{1}$ Center for Resources, Environment and Food Security, Key Laboratory of Plant-Soil Interactions, Ministry of Education, \\ College of Resources \& Environmental Sciences, China Agricultural University, Beijing 100193, China; \\ ${ }^{2}$ School of Environment and Surveying Engineering, Suzhou University, Suzhou 234100, China; \\ ${ }^{3}$ Changsha Research Station for Agricultural Environment Monitoring \& Key Laboratory of Agro-Ecological Processes in \\ Subtropical Region, Institute of Subtropical Agriculture, Chinese Academy of Sciences, Changsha 410125, China
}

\begin{abstract}
With rapid economic growth in China, anthropogenic reactive nitrogen $(\mathrm{Nr})$ emissions have more than doubled over the last two or three decades. Atmospheric $\mathrm{Nr}$ pollution is an environmental concern in China especially in megacities such as Beijing. In order to identify the impact of emission sources on atmospheric $\mathrm{Nr}$ pollution, we measured atmospheric $\mathrm{Nr}$ concentrations and their isotopic composition $\left(\delta^{15} \mathrm{~N}\right)$ dynamics at three typical sites: landfill, pig farm and road traffic sites in Beijing from April 2010 to March 2011. Passive samplers were used for monitoring ammonia $\left(\mathrm{NH}_{3}\right)$ and nitrogen dioxide $\left(\mathrm{NO}_{2}\right)$, two major $\mathrm{Nr}$ species, while their $\delta^{15} \mathrm{~N}$ values were measured by a diffusion method combined with mass spectrometer approach. The raw water pool of the landfill and fattening house of the pig farm were important $\mathrm{NH}_{3}$ sources with mean $\mathrm{NH}_{3}$ concentrations being 2,829 and $2,369 \mu \mathrm{g} / \mathrm{m}^{3}$, respectively, while the road traffic site was a minor $\mathrm{NH}_{3}$ source $\left(10.6 \mu \mathrm{g} / \mathrm{m}^{3}\right)$. $\mathrm{NH}_{3}$ concentrations at sites besides the landfill and roads were high in summer and low in winter due to the annual variation of temperature and the change of emission source intensity. In contrast, the $\mathrm{NH}_{3}$ concentrations inside the pig farm house were high in winter and low in summer, for the barn windows were open in summer and closed in winter. The mean $\mathrm{NO}_{2}$ concentrations were $89.8,32.9$ and $23.0 \mu \mathrm{g} / \mathrm{m}^{3}$ at the road traffic, the landfill and pig farm sites, respectively. Due to vehicle fuel combustion, $\mathrm{NO}_{2}$ concentration at the road traffic was the highest among the three sources, and the road traffic was a main $\mathrm{NO}_{2}$ emission source. $\mathrm{PM}_{10}, \mathrm{pNH}_{4}{ }^{+}$and $\mathrm{pNO}_{3}{ }^{-}$concentrations in particulate matter were higher in summer than in winter (except $\mathrm{PM}_{10}$ for the pig farm). The $\delta^{15} \mathrm{NH}_{3}$ values ranged from $-19.14 \%$ o to $7.82 \%$, with an average of $-0.05 \%$ or the landfill site, and the lowest values were observed in June and July. The $\delta^{15} \mathrm{NH}_{3}$ values for the pig farm site ranged from $-29.78 \%$ o to $-14.05 \%$ with an average of $-24.51 \%$, and the $\delta^{15} \mathrm{NH}_{3}$ values were more negative in summer than in the other seasons. The $\delta^{15} \mathrm{NO}_{2}$ values were $-9.63 \%$ o to $7.04 \%$ with an average of $-3.72 \%$ for the road traffic site. The $\delta^{15} \mathrm{NO}_{2}$ values were more negative in summer than those in the other seasons. The different $\delta^{15} \mathrm{~N}$ values for the various $\mathrm{Nr}$ species in different sources may serve as important indicators for identifying atmospheric $\mathrm{Nr}$ sources in megacities. The results may also provide the theoretical basis for research on the atmospheric $\mathrm{N}$ deposition and its sources.
\end{abstract}

Keywords: atmospheric reactive $\mathrm{N}$ pollution; emission sources; $\mathrm{NH}_{3} ; \mathrm{NO}_{2}$; particulate matter

Citation: LIU Jieyun, ZHANG Ying, LIU Xuejun, TANG Aohan, QIU Husen, ZHANG Fusuo. 2016. Concentrations and isotopic characteristics of atmospheric reactive nitrogen around typical sources in Beijing, China. Journal of Arid Land, 8(6): 910-920. doi: 10.1007/s40333-016-0020-0

*Corresponding author: LIU Xuejun (E-mail: liu310@cau.edu.cn)

Received 2016-01-02; revised 2016-05-20; accepted 2016-05-24

(C) Xinjiang Institute of Ecology and Geography, Chinese Academy of Sciences, Science Press and Springer-Verlag Berlin Heidelberg 2016 
Atmospheric nitrogen $(\mathrm{N})$ deposition refers to the process whereby air-borne nitrogenous compounds are deposited on the Earth surface by precipitation (wet) or dry deposition (Liu et al., $2006,2013)$. The global rate of reactive $\mathrm{N}(\mathrm{Nr})$ production increased from approximately $15 \mathrm{Tg}$ $\mathrm{N} / \mathrm{a}$ in 1860 to $187 \mathrm{Tg} \mathrm{N} / \mathrm{a}$ in 2005 and more than half of this $\mathrm{N}$ is deposited onto the ground (Gruber and Galloway, 2008). The $\mathrm{N}$ input induces a considerable burden on ecosystems, causing changes in biodiversity, increasing tree growth in forests and leading to the eutrophication of aquatic and terrestrial systems (Liu et al., 2011). Investigations of the level, distribution and sources of atmospheric $\mathrm{N}$ deposition are crucial for the further study of its ecological and environmental impacts (Liu et al., 2011, 2013).

The main sources of atmospheric $\mathrm{Nr}$ are agricultural fertilization, livestock production (e.g. pigs, cattle and poultry), biomass burning, fossil-fuel combustion by power plants and automobiles, combustion processes in industry and households and others (He et al., 2007; Clarisse et al., 2009). By 2050, the global emissions of $\mathrm{NH}_{3}$ are expected to double, principally owing to the demographic growth, the changes in food preferences and the agricultural intensification (Clarisse et al., 2009). Volatilization from livestock manures and mineral fertilizer application is the major source of $\mathrm{NH}_{3}$ emissions, accounting for approximately $80 \%-90 \%$ of the total anthropogenic emission (Bouwman and Van Der Hoek, 1997). In China, agriculture contributes about $80 \%$ of total $\mathrm{NH}_{3}$ emission, and the biggest contributor is livestock production (about $30 \%-60 \%$; Ianniello et al., 2010; Kang et al., 2016). In the UK, Netherlands, Denmark and Germany, $\mathrm{NH}_{3}$ emissions from livestock accounted for $75 \%, 85 \%, 82 \%$ and $76 \%$ of total $\mathrm{NH}_{3}$ emission, respectively (Vranken et al., 2004). Landfills represent a potential source of the offensive odors (Ding et al., 2012), in which, especially $\mathrm{NH}_{3}$, exerts a disproportionately adverse effect on the environment, especially on human health (Dincer et al., 2006). In recent years, $\mathrm{NH}_{3}$ emission in urban environment has increased due to over-reduction of nitrogen oxide compounds in catalytic converters in vehicles (Perrino et al., 2002; Shen et al., 2009; Felix et al., 2014). In the US, the contribution of traffic was about $5 \%$ to the total $\mathrm{NH}_{3}$ emissions (Kean et al., 2009). Sutton et al. (2000) pointed to the transport sector as the main source of non-agricultural $\mathrm{NH}_{3}$ emissions $(16 \%)$ in the UK, in which $94 \%$ of transport emissions are due to gasoline cars with catalysts.

Isotope ratio determination provides a useful tool for assessing the importance of various sources and sinks as well as physical and chemical reactions of trace constituents in the atmosphere, since $\mathrm{N}$ isotope compositions are different among various $\mathrm{N}$ pools (Proemse et al., 2013). Some previous studies have involved $\delta^{15} \mathrm{~N}$ signatures as tracers of $\mathrm{N}$ deposition sources. $\delta^{15} \mathrm{NH}_{3}$ values from animal waste ranged from $-15.2 \%$ to $-8.9 \%$ (Freyer, 1978; Heaton, 1986), and from $-7.0 \%$ to $-2.0 \%$ from coal combustion (Heaton, 1986). $\delta^{15} \mathrm{NO}_{2}$ values from vehicle exhaust were between $-13 \%$ and $-2 \%$ (Heaton, 1990). However, Moore (1977) reported that the $\delta^{15} \mathrm{NO}_{2}$ value from vehicles was $3.7 \%$. These data were mostly obtained from sites near to the emission sources rather than directly from the atmospheric reactive nitrogen compounds. Based on $\delta^{15} \mathrm{~N}$ values, we attempted to identify the main atmospheric $\mathrm{N}$ deposition sources in typical source areas (Xiao and Liu, 2002; Xiao et al., 2010). For example, Zhang et al. (2008) analyzed the $\delta^{15} \mathrm{NH}_{4}-\mathrm{N}$ and $\delta^{15} \mathrm{NO}_{3}{ }^{-}-\mathrm{N}$ in precipitation in the North China Plain (NCP, including two rural sites and two suburban sites). The results showed that the $\delta^{15} \mathrm{NH}_{4}{ }^{+}-\mathrm{N}$ and $\delta_{15} \mathrm{NO}_{3}{ }^{-} \mathrm{N}$ values at the rural sites were more negative than those at the suburban sites and the authors concluded that atmospheric $\mathrm{N}$ deposition was mainly derived from local agricultural sources in rural areas of NCP. In recent years, moss sampling and analysis was regarded as an effective tool to indicate the sources and transformation of atmospheric reactive N (Bragazza et al., 2005). Some studies with mosses were also conducted to identify the main atmospheric $\mathrm{N}$ source in area based on reported $\delta^{15} \mathrm{~N}$ for different $\mathrm{N}$ emission sources (Xiao and Liu, 2002; Liu et al., 2008). For example, Liu et al. (2008) reported negative $\delta^{15} \mathrm{~N}$ values in the Guiyang area and concluded that $\mathrm{N}$ deposition in Guiyang was dominated by $\mathrm{NH}_{\mathrm{x}}-\mathrm{N}$ from city wastes and sewage, according to the reported $\delta^{15} \mathrm{~N}$ values from different sources for $\mathrm{NH}_{3}$ and $\mathrm{NO}_{2}$ (Freyer, 1978; Heaton, 1987, 1990).

There are only few reports on using $\delta^{15} \mathrm{~N}$ as a tracer of atmospheric $\mathrm{N}$ deposition to identify the major emission sources of reactive $\mathrm{N}$ together with the $\mathrm{N}$ concentration in air. Only a few studies investigated the specific $\delta^{15} \mathrm{~N}$ values for one or two sources (Freyer, 1978; Heaton, 1990). In 
addition, most previous studies focused on wet $\mathrm{N}$ deposition (Xiao et al., 2010), and research on dry $\mathrm{N}$ deposition is still scarce.

Beijing is one of the global megacities due to the $19.6 \times 10^{6}$ inhabitants in 2010 (Beijing Municipal Bureau of Statistics, http://www.bjstats.gov.cn). Rapid economic growth and the urbanization aggravated air pollution in Beijing and presented a great challenge for both scientific research and management of urban and regional air quality (Meng et al., 2011). In the present study, we selected three emission sources (including landfill, pig farm and road traffic) in order to investigate and quantify the concentrations of different atmospheric $\mathrm{Nr}$ compounds and to test the potential use of $\delta^{15} \mathrm{~N}$ signatures to identify different sources.

\section{Materials and methods}

\subsection{Study area}

Beijing, the study region, located in the north edge of NCP, is characterized by a temperate semi-humid monsoon climate. The mean annual precipitation, average air temperature, frost-period and sunshine hours are $644 \mathrm{~mm}, 14.0^{\circ} \mathrm{C}, 190 \mathrm{~d}$ and 2,400 h, respectively. Rainfall and heat resources are in the same seasons, and approximately $70 \%$ of the rainfall is in summer. Beijing is a famous megacity worldwide, where the rapid economic growth may have damaged its environment, including air pollution and shortage of freshwater.

\subsection{Sampling sites}

Three monitoring sites around typical $\mathrm{Nr}$ emission sources in Beijing were selected to determine the $\mathrm{Nr}$ concentrations and the isotopic characteristics. One is Liulitun landfill, which is located in Yongfeng village of the Haidian District. The second is the Beilangzhong pig farm, which is located in the Shunyi District. As the third emission source, we selected road traffic and chose the Yuanmingyuan West Road beside the west campus gate of the China Agricultural University (Table 1; Fig. 1). The sampling site in the landfill was above its raw water pool, which was one of the major sources of $\mathrm{NH}_{3}$ emission in this landfill. $\mathrm{NH}_{3}$ concentration at this site was the maximum in the landfill. The raw water pool was covered during the sampling period. The Beilangzhong pig farm has $8 \times 10^{3}$ breeding pigs. The sampling site in the pig farm was located in the fattening house, thus representing the $\mathrm{NH}_{3}$ concentration in the pig barn. The windows of the fattening house were open in summer and closed in winter, which influenced the $\mathrm{NH}_{3}$ concentrations. At the selected road site, the average daily traffic volume was $8 \times 10^{4}$ vehicles. The sampling site of the traffic source was located in the green belt of the road, which was outside of the north fifth ring, and the pollution included the center of city and suburb, so the $\mathrm{NH}_{3}$ concentration of this sampling site most probably represents the average reactive $\mathrm{N}$ emissions from traffic in Beijing.

\subsection{Sampling and analyzing}

Atmospheric $\mathrm{NH}_{3}$ near the three emission sources was collected with passive samplers of the ALPHA type (Adapted Low-cost Passive High Absorption) (Tang et al., 2001), which was supplied by the CEH (Centre for Ecology and Hydrology) in Edinburgh, Great Britain. A sampling membrane was the main component of the passive sampler, which was also supplied and tested by $\mathrm{CEH}$, and was widely adopted by the $\mathrm{N}$ deposition network of the European Union. Three replicates were arranged at each monitoring sites. Meanwhile, one passive sampler was prepared in the laboratory as a control. The samples were collected every week and conserved at $4^{\circ} \mathrm{C}$. All samples and controls were analyzed within one month. To estimate the $\mathrm{NH}_{3}$ concentrations,

Table 1 Basic information on the sampling sites

\begin{tabular}{cccc}
\hline Source & Sampling site & Period of sampling & Sampling type \\
\hline Landfill & Raw water pool & $2010 / 04 / 08-2011 / 03 / 30$ & Suburb site \\
Pig farm & Fattening house & $2010 / 05 / 04-2011 / 01 / 17$ & Suburb site \\
Road traffic & Yuanmingyuan West Road & $2010 / 04 / 08-2011 / 03 / 30$ & Urban site \\
\hline
\end{tabular}



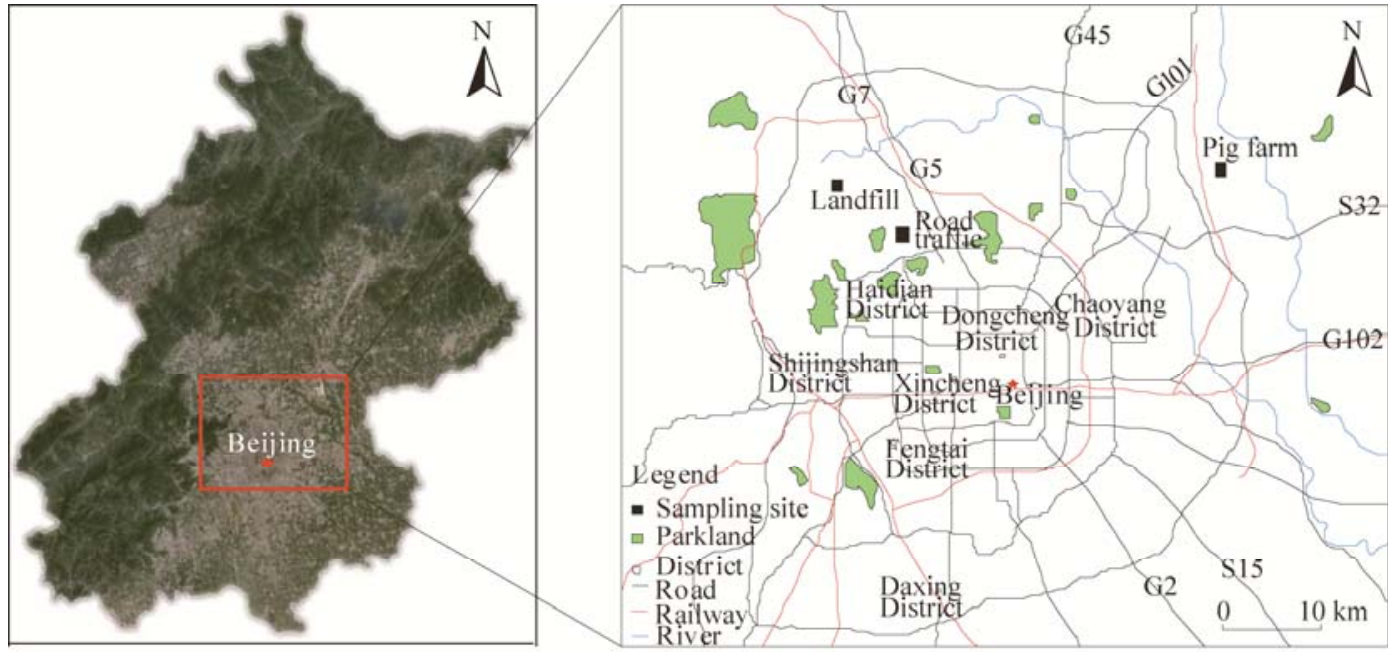

Fig. 1 Location of the sampling sites in Beijing

we extracted the sampling membrane with $10 \mathrm{~mL}$ high purity water for $1 \mathrm{~h}$. The mmonium in the solutions was measured with an AA3 continuous-flow analyzer (Bran+Luebbe GmbH, Norderstedt, Germany). The $\mathrm{NH}_{3}$ concentrations $\left(\mu \mathrm{g} / \mathrm{m}^{3}\right)$ in the air were calculated with the following equation:

$$
C=(17 / 14) \times\left(m_{e}-m_{b}\right) / V \text {. }
$$

Where, $m_{e}$ represents the mass of $\mathrm{NH}_{3}$ in the samples $(\mu \mathrm{g}), m_{b}$ the mass of $\mathrm{NH}_{3}$ in the control $(\mu \mathrm{g})$, and $V$ the effective sampling volume, which was determined by the sampling time and the sampling rate of the sampler. $V$ was calculated by the following equation:

$$
V=D A t / L \text {. }
$$

Where, $t$ represents the sampling time (h), $D$, the sampling rate of the sampler, $D=2.09 \times 10^{-5} \mathrm{~m}^{2} / \mathrm{s}$ at $10^{\circ} \mathrm{C}, A$, the effective sampling area, $A=3.463 \times 10^{-4} \mathrm{~m}^{2}$, and $L$, the length of the sampler, $L=0.006 \mathrm{~m}$.

Atmospheric $\mathrm{NO}_{2}$ was collected by the passive sampler Gradko diffusion tubes from ECN (the UK Environmental Change Network Website, http://data.gov.uk/dataset). The sampler consisted of a tube, two caps and stainless steel mesh disks. Two dry disks were placed in the caps and $30 \mu \mathrm{L}$ of a $20 \%$ aqueous solution of triethanolamine was pipetted into the gray cap to prepare them for use. The samplers were hung at $2 \mathrm{~m}$ above the ground and exposed in the air for two weeks. Three replicates were arranged at each monitoring site, respectively. Meanwhile, one passive sampler was prepared in the laboratory as a control. The conservation method was the same as for $\mathrm{NH}_{3}$ samples. To estimate the $\mathrm{NO}_{2}$ concentration, we extracted the disks with a solution containing sulphanilamide, $\mathrm{H}_{3} \mathrm{PO}_{4}$ and $\mathrm{N}-1-\mathrm{Naphthylethylene-diamine}$ dihydrochloride and then measured with a colorimetric method at a wavelength of $542 \mathrm{~nm}$. The $\mathrm{NO}_{2}$ concentrations in the air were calculated with the following equation:

$$
C=\left(m_{e}-m_{b}\right) / V \text {. }
$$

Where, $m_{e}$ represents the mass of $\mathrm{NO}_{2}$ in the samples $(\mu \mathrm{g}), m_{b}$ the mass of $\mathrm{NO}_{2}$ in the control $(\mu \mathrm{g})$, and $V$ the effective sampling volume, which was determined by the sampling time and the sampling rate of the sampler. $V$ was calculated by the following equation:

$$
V=R \times t \text {. }
$$

Where, $R$ represents the sampling rate of the sampler, $R=0.0000688 \mathrm{~m}^{3} / \mathrm{h}$, and $t$ the sampling time (h).

Atmospheric particulate matter $\left(\mathrm{PM}_{10}\right.$ in this study) was collected by frmOMNI ambient air sampler (BGI, USA). In the sampler, there was a membrane (Whatman, the UK) for collecting particulate matter. The Whatman membrane was balanced in condition of $22^{\circ} \mathrm{C}$ and $50 \%$ of relative humidity for one day before and after sampling, and then was weighed with microgram balance. The difference of the weight between after and before sampling was the weight of particulate matter. Then the membrane was extracted with $10 \mathrm{~mL}$ high purity water for $1 \mathrm{~h}$. 
Ammonium and nitrate in the solutions were measured with an AA3 continuous-flow analyzer (Bran+Luebbe GmbH, Norderstedt, Germany).

$\delta^{15} \mathrm{~N}$ values of $\mathrm{NH}_{3}$ and $\mathrm{NO}_{2}$ were measured by the mass spectrometer (Delta Plus, Finnigan, Pittsburg, PA, USA; Brooks et al., 1989).

\subsection{Data analysis}

The SPSS 20.0 (SPSS Inc., Chicago, IL) was used to perform one-way ANOVA, and the significance was set at the $P<0.05$ level and tested using the least significant difference (LSD) method.

\section{Results}

\subsection{Atmospheric concentrations of $\mathrm{NH}_{3}$ and $\mathrm{NO}_{2}$}

$\mathrm{NH}_{3}$ concentrations during the sampling period at the three observation sites in Beijing are shown in Fig. 2. It is obvious that $\mathrm{NH}_{3}$ concentrations varied greatly among three sites. The $\mathrm{NH}_{3}$ concentrations at the raw water pool in the landfill and the fattening house in the pig farm ranged from 137 to 6,581 and 195 to $6,086 \mu \mathrm{g} / \mathrm{m}^{3}$, with averages of 2,829 and $2,369 \mu \mathrm{g} / \mathrm{m}^{3}$, respectively (Table 2). The $\mathrm{NH}_{3}$ concentrations at the road traffic site were far lower than other two sites and varied from 5.6 to $34.1 \mu \mathrm{g} / \mathrm{m}^{3}$, with an average of $10.6 \mu \mathrm{g} / \mathrm{m}^{3}$ (Table 2).

As shown in Fig. 2, $\mathrm{NH}_{3}$ concentrations exhibited distinct temporal and seasonal variations in the three sources. At the landfill and road traffic sites, $\mathrm{NH}_{3}$ values were higher in summer (spring and summer at the landfill site) than in other seasons, especially in winter, and had a small peak in April. The highest monthly averages of $\mathrm{NH}_{3}$ occurred in June at the landfill site and in July at the road traffic site. The lowest values appeared in January at the landfill site and in February at the road traffic site. Seasonal average concentrations of $\mathrm{NH}_{3}$ were 3,635, 3,248, 2,369 and 2,197 $\mu \mathrm{g} / \mathrm{m}^{3}$ at the landfill site, and $12.3,21.8,14.3$ and $9.1 \mu \mathrm{g} / \mathrm{m}^{3}$ at the road traffic site in spring, summer, autumn and winter, respectively. On the contrary, $\mathrm{NH}_{3}$ concentrations at the fattening house in the pig farm showed high in winter and low in summer, and the highest average value was in December.

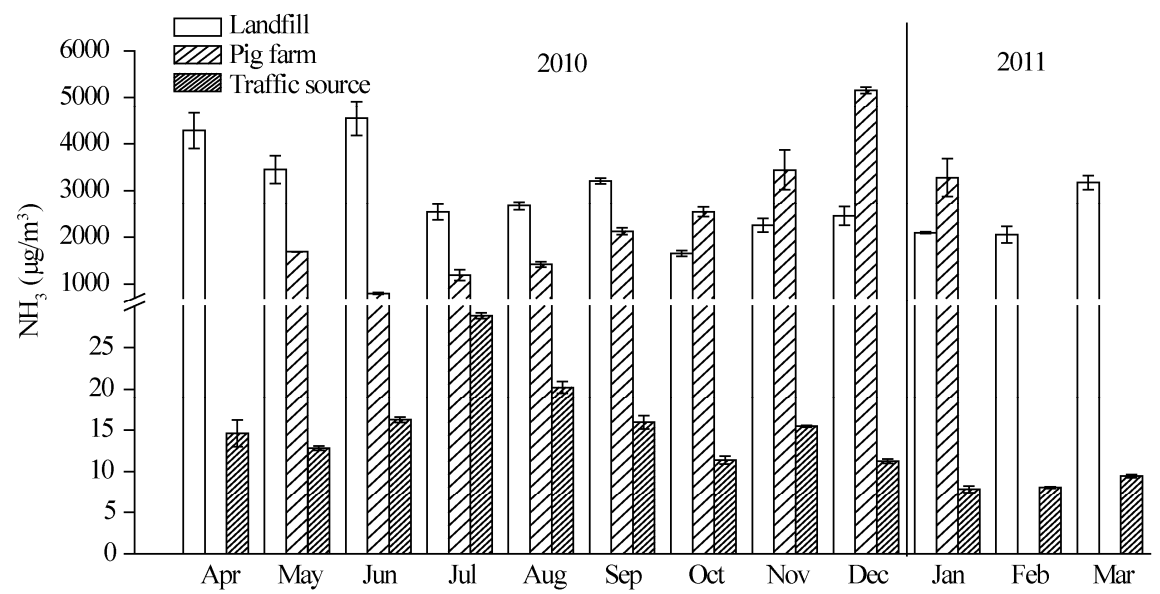

Fig. 2 Monthly variations of $\mathrm{NH}_{3}$ concentration at the monitoring sites near the landfill, the pig farm and the road traffic sites. Bars above or within the columns represent standard deviations; $n=3$.

As shown in Table 2, large variations of average $\mathrm{NO}_{2}$ concentrations were observed among the three sampling sites. $\mathrm{NO}_{2}$ concentrations at the road traffic site were significantly higher than those at the landfill and pig farm sites, which were typical $\mathrm{NH}_{3}$ emission sources $(P<0.05)$. The mean $\mathrm{NO}_{2}$ concentration at the landfill site was significantly higher than that at the pig farm site $(P<0.05)$. The $\mathrm{NO}_{2}$ emissions from the landfill, as a typical $\mathrm{NH}_{3}$ emission source, should not be ignored. 
Table 2 Mean concentrations of $\mathrm{NH}_{3}$ and $\mathrm{NO}_{2}$ during the sampling period

\begin{tabular}{ccc}
\hline Source & $\mathrm{NH}_{3}\left(\mu \mathrm{g} / \mathrm{m}^{3}\right)$ & $\mathrm{NO}_{2}\left(\mu \mathrm{g} / \mathrm{m}^{3}\right)$ \\
\hline Landfill & $2,829^{\mathrm{a}}$ & $32.9^{\mathrm{b}}$ \\
Pig farm & $2,369^{\mathrm{b}}$ & $23.0^{\mathrm{c}}$ \\
Road traffic & $10.6^{\mathrm{c}}$ & $89.8^{\mathrm{a}}$ \\
\hline
\end{tabular}

Note: Different lowercases in the same column indicate significant differences between the treatments at the $P<0.05$ level.

\subsection{Concentrations of $\mathrm{PM}_{10}, \mathrm{pNH}_{4}{ }^{+}$and $\mathrm{pNO}_{3}{ }^{-}$}

Atmospheric concentrations of particulate matter $\left(\mathrm{PM}_{10}\right)$ and $\mathrm{NH}_{4}{ }^{+}$and $\mathrm{NO}_{3}{ }^{-}$in particulate matter $\left(\mathrm{pNH}_{4}{ }^{+}\right.$and $\left.\mathrm{pNO}_{3}{ }^{-}\right)$were measured in summer and winter near the landfill, the pig farm and the road traffic sites. The concentrations of $\mathrm{PM}_{10}, \mathrm{pNH}_{4}{ }^{+}$and $\mathrm{pNO}_{3}{ }^{-}$are shown in Table 3. The concentrations of $\mathrm{PM}_{10}$ in summer were significantly higher than those in winter near the landfill and the road traffic sites $(P<0.05)$. However, in the fattening house of the pig farm, the concentrations of $\mathrm{PM}_{10}$ were significantly lower in summer than in winter $(P<0.05)$. The $\mathrm{pNO}_{3}{ }^{-}$ concentrations were significantly $(P<0.05)$ higher in summer than in winter near the three sources. The $\mathrm{pNH}_{4}{ }^{+}$concentrations in summer were higher than in winter, and the differences were significant between the landfill and the pig farm sites $(P<0.05)$.

Table 3 Concentrations of $\mathrm{PM}_{10}, \mathrm{pNH}_{4}{ }^{+}$and $\mathrm{pNO}_{3}{ }^{-}$in the landfill, the pig farm and the road traffic sites

\begin{tabular}{|c|c|c|c|c|}
\hline \multirow{2}{*}{ Source } & \multirow{2}{*}{ Season } & $\mathrm{PM}_{10}$ & $\mathrm{pNH}_{4}^{+}$ & $\mathrm{pNO}_{3}{ }^{-}$ \\
\hline & & \multicolumn{3}{|c|}{$\left(\mu \mathrm{g} / \mathrm{m}^{3}\right)$} \\
\hline \multirow[t]{2}{*}{ Landfill } & Summer & $289.1^{\mathrm{a}}$ & $19.3^{\mathrm{a}}$ & $31.2^{\mathrm{a}}$ \\
\hline & Winter & $136.5^{\mathrm{b}}$ & $2.2^{\mathrm{b}}$ & $2.3^{\mathrm{b}}$ \\
\hline \multirow[t]{2}{*}{ Pig farm } & Summer & $426.6^{\mathrm{b}}$ & $25.1^{\mathrm{a}}$ & $43.7^{\mathrm{a}}$ \\
\hline & Winter & $4,456^{\mathrm{a}}$ & $10.4^{\mathrm{b}}$ & $7.1^{\mathrm{b}}$ \\
\hline \multirow[t]{2}{*}{ Road traffic } & Summer & $289.8^{\mathrm{a}}$ & $4.1^{\mathrm{a}}$ & $29.7^{\mathrm{a}}$ \\
\hline & Winter & $121.4^{\mathrm{b}}$ & $3.8^{\mathrm{a}}$ & $10.3^{b}$ \\
\hline
\end{tabular}

Note: Different lowercases in the same column indicate significant differences between the seasons at the $P<0.05$ level for each source.

\subsection{Characteristics of $\delta^{15} \mathrm{NH}_{3}$ and $\delta^{15} \mathrm{NO}_{2}$}

The average of $\delta^{15} \mathrm{NH}_{3}$ of the landfill was $-0.05 \%$ (Fig. 2), ranging from $-19.14 \%$ o to $7.82 \%$ and was lower in summer, especially in June and July 2010, than in other seasons. The monthly averages of $\delta^{15} \mathrm{NH}_{3}$ varied near 0 in spring. In autumn, the monthly averages of $\delta^{15} \mathrm{NH}_{3}$ showed little variance and kept positive. The $\delta^{15} \mathrm{NH}_{3}$ of the pig farm ranged from $-29.78 \%$ o to $-14.05 \%$, with an average of $-24.51 \%$ (Fig. 3). Similar to the $\delta^{15} \mathrm{NH}_{3}$ in the landfill, the $\delta^{15} \mathrm{NH}_{3}$ in the pig farm were low in summer, and gradually increased from June to August. The high values occurred in May and October 2010.

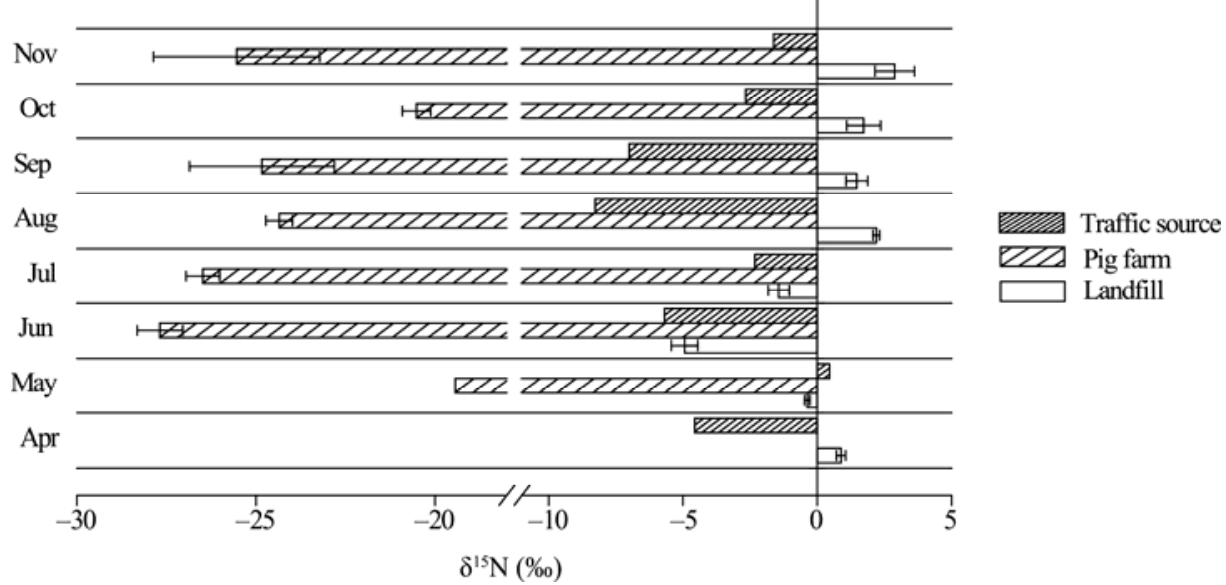

Fig. 3 Dynamics of $\delta^{15} \mathrm{NH}_{3}$ at monitoring sites near the landfill and the pig farm, and $\delta^{15} \mathrm{NO}_{2}$ near the road traffic site in 2010. Bars above or within the columns represent standard deviations; $n=3$. 
As seen in Fig. 3, the $\delta^{15} \mathrm{NO}_{2}$ values of the road traffic ranged from $-9.63 \%$ o to $7.04 \%$, with an average of $-3.72 \%$. The monthly averages of $\delta^{15} \mathrm{NO}_{2}$ values showed a large variance during the sampling period. In summer, the $\delta^{15} \mathrm{NO}_{2}$ values were more negative than those in spring and autumn. The high average $\delta^{15} \mathrm{NO}_{2}$ value occurred in May. In autumn, the monthly averages of $\delta^{15} \mathrm{NO}_{2}$ values gradually increased from September to November.

\section{Discussion}

\subsection{Concentrations of $\mathrm{NH}_{3}$ near the emission sources}

According to previous reports, landfills and pig farms represent major $\mathrm{NH}_{3}$ emission sources (Aneja et al., 2001; He et al., 2011). Recently, road traffic has gained increasing interest as an important $\mathrm{NH}_{3}$ emission source (Frati et al., 2006). In this study, the average $\mathrm{NH}_{3}$ concentrations were $2,829,2,369$ and $10.6 \mu \mathrm{g} / \mathrm{m}^{3}$ at the landfill, the pig farm and the road traffic sites, respectively.

In this study, the $\mathrm{NH}_{3}$ concentrations over the raw water pool in the landfill were consistent with the results (520 to $4,460 \mu \mathrm{g} / \mathrm{m}^{3}$ ) of Ding et al. (2012). The raw water was the leachate from the landfill, so the $\mathrm{NH}_{3}$ concentration showed a large variation with the changes of waste composition. The $\mathrm{NH}_{3}$ concentrations over the raw water were influenced by temperature and precipitation (Marttinen et a1., 2002). The decomposition of waste is an enzymatic reaction, which is sensitive to temperature (Barlaz et al., 1987). In Beijing, the temperature was above $20^{\circ} \mathrm{C}$ from April to September, which was beneficial for the waste decomposition. In spring, especially in April, the temperature suddenly increased and caused the accumulated $\mathrm{NH}_{3}$ emission from the decomposition in winter. In summer, the high temperature promoted the decomposition and $\mathrm{NH}_{3}$ emission. In addition, the wastes in summer were fruits, vegetables, grains and so on, which were easy to be decomposed to $\mathrm{NH}_{3}$. Moreover, the rainfall was supplied enough water for the microorganism decomposition in the landfill in summer. In autumn and winter, small precipitation and low temperature did not favor the activities of microorganisms, thus leading to low $\mathrm{NH}_{3}$ concentrations in winter.

Previous work has shown that $\mathrm{NH}_{3}$ emission from livestock accounts $70 \%$ for the total $\mathrm{NH}_{3}$ emissions in the world (Van Der Hoek, 1998). Livestock housing and spreading of manures account approximately $43 \%$ and $40 \%$ of the total $\mathrm{NH}_{3}$ losses from pig farms (Rebolledo et al., 2013). The $\mathrm{NH}_{3}$ concentrations in the fattening house $\left(2,326 \mu \mathrm{g} / \mathrm{m}^{3}\right)$ in this study were lower than those reported in studies from Europe (Hayes et al., 2006). $\mathrm{NH}_{3}$ concentrations in the fattening house are influenced by the type of ventilation, the type of floor and the method of manure disposal (Blanes-Vidal et al., 2008; Xu et al., 2014). In this study, the pig farm was equipped with natural ventilation, cement floor and dry manure disposal and the excrements were kept in the barn for a short time, so the $\mathrm{NH}_{3}$ volatilization was small. During the sampling period, the door of the fattening house was open in summer, and closed in winter so the $\mathrm{NH}_{3}$ concentrations in the barn was high in winter and low in summer.

Road traffic has always been a major source of nitrogen oxides $\left(\mathrm{NO}_{\mathrm{x}}\right)$ emissions (Kirchner et al., 2005). With the increasing use of the three-way catalysts in petrol cars, road traffic has become an important source of $\mathrm{NH}_{3}$ emission in urban environments (Reche et al., 2012). $\mathrm{NH}_{3}$ is generated through the reaction taking place in the converter between NO and $\mathrm{H}$ (Perrino et al., 2002). In this study, the average $\mathrm{NH}_{3}$ concentration at the road traffic site was $10.6 \mu \mathrm{g} / \mathrm{m}^{3}$, which was consistent with the results of Reche et al. (2012). Due to the high temperature in summer, the $\mathrm{NH}_{3}$ volatilization and emissions were high. Additionally, high temperature increased emissions from biological sources, such as humans, sewage and garbage collection systems, so that the $\mathrm{NH}_{3}$ concentrations near the road were higher in summer than in winter (Reche et al., 2012). Moreover, wind speed is negatively correlated with $\mathrm{NH}_{3}$ concentration because of the turbulent diffusion (Lin et al., 2011; Meng et al., 2011). In Beijing, the wind speed is normally higher in winter than in summer, the relative high wind speed together with low temperature may contribute to the low $\mathrm{NH}_{3}$ concentration in winter. 


\subsection{Concentrations of $\mathrm{NO}_{2}$ near the emission sources}

Fuel combustion represents the major source of man-made $\mathrm{NO}_{\mathrm{x}}$ (Kirchner et al., 2005). Although $\mathrm{NO}_{\mathrm{x}}$ emissions by gasoline powered cars could be reduced following the introduction of three-way catalytic converters (Kean et al., 2000), $\mathrm{NO}_{\mathrm{x}}$ emissions remain a problem for the environment due to the increasing road traffic (Kirchner et al., 2005). In this study, the average $\mathrm{NO}_{2}$ concentration near the road traffic site $\left(89.8 \mu \mathrm{g} / \mathrm{m}^{3}\right)$ was much higher than the annual limit value $\left(40.0 \mu \mathrm{g} / \mathrm{m}^{3}\right)$ in Europe (ETC, 2011). During the sampling period, the smaller precipitation than usual was promoting the generation of an inversion layer, and not beneficial for the wet deposition (and thus removal from the atmosphere) of pollutants. In addition, the vehicle number is rapidly increasing in Beijing, so are the $\mathrm{NO}_{2}$ emissions. The average $\mathrm{NO}_{2}$ concentrations at the landfill and pig farm were significantly lower than those at the road traffic site $(P<0.05)$. Especially, the mean $\mathrm{NO}_{2}$ concentration in the fattening house $\left(23.0 \mu \mathrm{g} / \mathrm{m}^{3}\right)$ was just slightly higher than in urban background sites in London (an average of $17.3 \mu \mathrm{g} / \mathrm{m}^{3}$ ) (Carslaw and Carslaw, 2007). In these sources, fuel combustion during the heating in winter also contributed to the $\mathrm{NO}_{2}$ emissions.

\subsection{Particulate matter $\left(\mathrm{PM}_{10}\right)$ formation near the emission sources}

$\mathrm{PM}_{10}$ concentrations were very high near the three sources, and were higher in summer than in winter near the landfill and the road traffic sites (Table 3). The $\mathrm{PM}_{10}$ was influenced by temperature and precipitation. In winter, the $\mathrm{PM}_{10}$ concentrations were lower than in summer, so were the $\mathrm{pNH}_{4}{ }^{+}$and $\mathrm{pNO}_{3}{ }^{-}$values, which is not consistent with the findings by Pan et al. (2012). The main reason of the difference was that the precipitation in winter of 2010 was higher than other years (2007-2009), which took away the $\mathrm{PM}_{10}$ from air. However, the $\mathrm{PM}_{10}$ measurement near the pig farm was in the barn, and was not influenced by precipitation. In winter, the window of the fattening house was closed, so the $\mathrm{PM}_{10}$ concentration was higher than those in summer. The correlation between $\mathrm{pNH}_{4}{ }^{+}$and $\mathrm{pNO}_{3}{ }^{-}$is shown in Fig. $4, \mathrm{pNH}_{4}{ }^{+}$and $\mathrm{pNO}_{3}{ }^{-}$values were significantly correlated near the landfill and the pig farm $(P<0.01)$, which indicates that most of the $\mathrm{pNH}_{4}{ }^{+}$may be in the form of $\mathrm{NH}_{4} \mathrm{NO}_{3}$ in particulate matter, which is consistent with the findings by Shen et al. (2009).
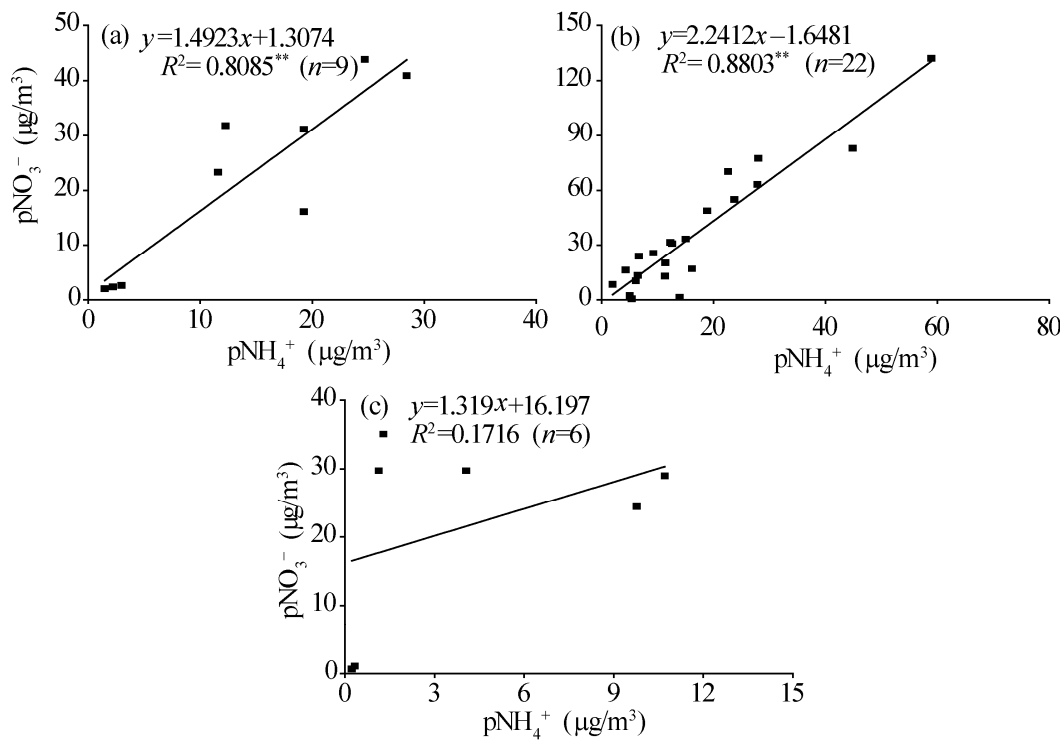

Fig. 4 The correlation of $\mathrm{pNH}_{4}{ }^{+}$and $\mathrm{pNO}_{3}{ }^{-}$in $\mathrm{PM}_{10}$ at monitoring sites near the landfill (a), the pig farm (b) and the road traffic site (c), respectively. ${ }^{* *}$ represents a significant correlation at $P<0.01$ level.

\subsection{Characteristics of $\delta^{15} \mathrm{NH}_{3}$ and $\delta^{15} \mathrm{NO}_{2}$}

The $\delta^{15} \mathrm{~N}$ values of atmospheric $\mathrm{N}$ sources ranged from $-15 \%$ o to $10 \%$, with the oxidized $\mathrm{N}\left(\mathrm{NO}_{\mathrm{x}}\right)$ being more positive and the reduced $\mathrm{N}\left(\mathrm{NH}_{\mathrm{x}}\right)$ being more negative (Moore, 1977; Freyer, 1978; Heaton, 1987, 1990). In previous studies, $\delta^{15} \mathrm{~N}$ values of atmospheric $\mathrm{N}$ deposition were 
investigated with mosses as indicators (Liu et al., 2008; Xiao et al., 2010), while in this study, the $\delta^{15} \mathrm{~N}$ values were measured directly from the source emissions.

The mean $\delta^{15} \mathrm{NH}_{3}$ value from the raw water pool $(-0.05 \%$ ) in the landfill was higher than that from sewage $\left(\delta^{15} \mathrm{NH}_{3}\right.$ value ranged from $-15 \%$ to $-4 \%$ ) (Freyer, 1978; Heaton, 1986). This difference is plausible because the covered raw water pool slowed down $\mathrm{NH}_{3}$ volatilization from the water in this study. The lowest value was found in June and July (Fig. 3), when the temperature was high, which stimulated the $\mathrm{NH}_{3}$ volatilization and resulted in the depletion in ${ }^{15} \mathrm{~N}$ of $\mathrm{NH}_{3}$ due to the isotopic fractionation during the volatilization.

According to the $\delta^{15} \mathrm{~N}$ inventories of atmospheric $\mathrm{NH}_{3}$ (Freyer, 1978; Heaton, 1986), the $\delta^{15} \mathrm{NH}_{3}$ values of excretory wastes are $-15.2 \%$ to $-8.9 \%$, which is higher than the value in our study $(-24.51 \%$ in the fattening house). The difference may be explained from the systems of natural ventilation, cement floor and dry manure disposal. In the fattening house, the urine was cleared away from the barn, so the manure was dry, which promoted $\mathrm{NH}_{3}$ volatilization and resulted in $\mathrm{NH}_{3}$ in the atmosphere being depleted in ${ }^{15} \mathrm{~N}$.

$\delta^{15} \mathrm{~N}$ values for anthropogenic and natural $\mathrm{NO}_{\mathrm{x}}$ sources vary over a large range (Elliott et al., 2007). The ${ }^{15} \mathrm{~N} /{ }^{14} \mathrm{~N}$ ratio of $\mathrm{NO}_{2}$ emitted from vehicles was very high $\left(\delta^{15} \mathrm{NO}_{2}=5.7 \%\right.$ ) (Amman et al., 1999). Heaton (1990) reported that the isotope composition of $\delta^{15} \mathrm{NO}_{\mathrm{x}}$ emitted by vehicles and coal-fired power stations separated into two distinct groups: $\delta^{15} \mathrm{~N}<0 \quad(-13 \%$ o to $-2 \%$ ) for vehicles and $\delta^{15} \mathrm{~N}>0$ (6\% to $13 \%$ ) for coal-fired power stations. In this study, the result (mean $\delta^{15} \mathrm{NO}_{2}$ : $-3.72 \%$ ) was consistent with Heaton (1990), but lower than the results from Amman et al. (1999), which may be interpreted as a consequence of local conditions such as traffic density, mean distribution of heavy- and light-duty engines, and average combustion regimes in the engines (Amman et al., 1999). These mechanisms need more studies for elucidation. From Fig. $3, \delta^{15} \mathrm{NO}_{2}$ values varied over a large range and showed obvious seasonal variability. In summer, the mean $\delta^{15} \mathrm{NO}_{2}$ values were more negative than those in winter, which may be due to the fuel combustion in winter. The $\delta^{15} \mathrm{NO}_{2}$ values from fuel combustion were higher than those from vehicles (Heaton, 1990; Kiga et al., 2000).

\section{Conclusions}

In this study, concentrations of $\mathrm{NH}_{3}, \mathrm{NO}_{2}$ and $\mathrm{PM}_{10}$ and the $\delta^{15} \mathrm{~N}$ signatures for $\mathrm{NH}_{3}$ or $\mathrm{NO}_{2}$ near a landfill, a pig farm and a road traffic site were measured. The mean $\mathrm{NH}_{3}$ concentrations were $2,829,2,369$ and $10.6 \mu \mathrm{g} / \mathrm{m}^{3}$ in the raw water pool of the landfill, the fattening house of the pig farm and near the road traffic sites, respectively. Seasonal variances were observed in the three emission sources. The $\mathrm{NO}_{2}$ emissions from the three sources were also different, with mean concentrations of $32.9,23.0$ and $89.8 \mu \mathrm{g} / \mathrm{m}^{3}$, respectively. The $\mathrm{PM}_{10}, \mathrm{pNH}_{4}{ }^{+}$and $\mathrm{pNO}_{3}{ }^{-}$in the particulate matter were higher in summer than in winter near the landfill and road traffic sites, which was opposite to the $\mathrm{PM}_{10}$ concentrations in the fattening house of the pig farm. The $\mathrm{pNH}_{4}{ }^{+}$ may be in the form of $\mathrm{NH}_{4} \mathrm{NO}_{3}$ in particulate matter near the landfill and pig farm. The $\delta^{15} \mathrm{NH}_{3}$ values for the $\mathrm{NH}_{3}$ emission sources were different. The mean $\delta^{15} \mathrm{NH}_{3}$ value was $-0.05 \%$ for the landfill, and $-24.51 \%$ for the pig farm. The mean $\delta^{15} \mathrm{NO}_{2}$ value at the road traffic site was $-3.72 \%$. This was the first time to directly measure the $\delta^{15} \mathrm{~N}$ signatures for different atmospheric $\mathrm{N}$ emission sources, which can help in the identification of different atmospheric $\mathrm{Nr}$ sources in a peri-urban area.

\section{Acknowledgements}

The work was supported by the National Basic Research Program of China (2014CB954202), the National Natural Science Foundation of China $(40425007,41071151,31421092)$ and the Suzhou University Startup Foundation for Doctor (2015jb04). The authors would like to thank Prof. Andreas FANGMEIER for linguistic corrections and Ms. MENG Lingmin for her help in collecting air samples near a pig farm. 


\section{References}

Ammann M, Siegwolf R, Pichlmayer F, et al. 1999. Estimating the uptake of traffic-derived $\mathrm{NO}_{2}$ from ${ }^{15} \mathrm{~N}$ abundance in Norway spruce needles. Oecologia, 118(2): 124-131.

Aneja V P, Roelle P A, Murray G C, et al. 2001. Atmospheric nitrogen compounds II: emissions, transport, transformation, deposition and assessment. Atmospheric Environment, 35(11): 1903-1911.

Barlaz M A, Milke M W, Ham R K. 1987. Gas production parameters in sanitary landfill simulators. Waste Management \& Research, 5(1): 27-39.

Blanes-Vidal V, Hansen M N, Pedersen S, et al. 2008. Emissions of ammonia, methane and nitrous oxide from pig houses and slurry: Effects of rooting material, animal activity and ventilation flow. Agriculture, Ecosystems \& Environment, 124(3-4): 237-244.

Bouwman A F, Van Der Hoek K W. 1997. Scenarios of animal waste production and fertilizer use and associated ammonia emission for the developing countries. Atmospheric Environment, 31(24): 4095-4102.

Bragazza L, Limpens J, Gerdol R, et al. 2005. Nitrogen concentration and $\delta^{15} \mathrm{~N}$ signature of ombrotrophic Sphagnum mosses at different $\mathrm{N}$ deposition levels in Europe. Global Change Biology, 11(1): 106-114.

Brooks P D, Stark J M, McInteer B B, et al. 1989. Diffusion method to prepare soil extracts for automated nitrogen-15 analysis. Soil Science Society of America Journal, 53(6): 1707-1711.

Carslaw D C, Carslaw N. 2007. Detecting and characterising small changes in urban nitrogen dioxide concentrations. Atmospheric Environment, 41(22): 4723-4733.

Clarisse L, Clerbaux C, Dentener F, et al. 2009. Global ammonia distribution derived from infrared satellite observations. Nature Geoscience, 2(7): 478-483.

Dincer F, Odabasi M, Muezzinoglu A. 2006. Chemical characterization of odorous gases at a landfill site by gas chromatography-mass spectrometry. Journal of Chromatography A, 1122(1-2): 222-229.

Ding Y, Cai C Y, Hu B, et al. 2012. Characterization and control of odorous gases at a landfill site: A case study in Hangzhou, China. Waste Management, 32(2): 317-326.

Elliott E M, Kendall C, Wankel S D, et al. 2007. Nitrogen isotopes as indicators of $\mathrm{NO}_{\mathrm{x}}$ source contributions to atmospheric nitrate deposition across the Midwestern and Northeastern United States. Environmental Science \& Technology, 41(22): 7661-7667.

European Topic Centre on Air Pollution and Climate Change Mitigation (ETC). 2011. Report on the European Ambient Air Quality Monitoring and State in 2009. [2011-06-22]. http://acm.eionet.europa.eu/announcements/ann1308731514.

Felix J D, Elliott E M, Gish T, et al. 2014. Examining the transport of ammonia emissions across landscapes using nitrogen isotope ratios. Atmospheric Environment, 95: 563-570.

Frati L, Caprasecca E, Santoni S, et al. 2006. Effects of $\mathrm{NO}_{2}$ and $\mathrm{NH}_{3}$ from road traffic on epiphytic lichens. Environmental Pollution, 142(1): 58-64.

Freyer H D. 1978. Seasonal trends of $\mathrm{NH}_{4}{ }^{+}$and $\mathrm{NO}_{3}{ }^{-}$nitrogen isotope composition in rain collected at Jülich, Germany. Tellus, 30(1): 83-92.

Gruber N, Galloway J N. 2008. An Earth-system perspective of the global nitrogen cycle. Nature, 451(7176): 293-296.

Hayes E T, Curran T P, Dodd V A. 2006. Odour and ammonia emissions from intensive pig units in Ireland. Bioresource Technology, 97(7): 940-948.

He C E, Liu X J, Fangmeier A, et al. 2007. Quantifying the total airborne nitrogen input into agroecosystems in the North China Plain. Agriculture, Ecosystems \& Environment, 121(4): 395-400.

He P J, Yang N, Gu H L, et al. 2011. $\mathrm{N}_{2} \mathrm{O}$ and $\mathrm{NH}_{3}$ emissions from a bioreactor landfill operated under limited aerobic degradation conditions. Journal of Environmental Sciences, 23(6): 1011-1019.

Heaton T H E. 1986. Isotopic studies of nitrogen pollution in the hydrosphere and atmosphere: A review. Chemical Geology: Isotope Geoscience Section, 59: 87-102.

Heaton T H E. 1987. ${ }^{15} \mathrm{~N} /{ }^{14} \mathrm{~N}$ ratios of nitrate and ammonium in rain at Pretoria, South Africa. Atmospheric Environment (1967), 21(4): 843-852.

Heaton T H E. 1990. ${ }^{15} \mathrm{~N} /{ }^{14} \mathrm{~N}$ ratios of $\mathrm{NO}_{x}$ from vehicle engines and coal-fired power stations. Tellus B, 42(3): 304-307.

Ianniello A, Spataro F, Esposito G, et al. 2010. Occurrence of gas phase ammonia in the area of Beijing (China). Atmospheric Chemistry and Physics, 10(19): 9487-9503.

Kang Y N, Liu M X, Song Y, et al. 2016. High-resolution ammonia emissions inventories in China from 1980 to 2012. Atmospheric Chemistry and Physics, 16(4): 2043-2058.

Kean A J, Harley R A, Littleton D, et al. 2000. On-road measurement of ammonia and other motor vehicle exhaust emissions. In: 
Proceedings of the 10th CRC On-road Vehicle Emissions Workshop. San Diego, CA: Hyatt Islandia Hotel, 27-29.

Kiga T, Watanabe S, Yoshikawa K, et al. 2000. Evaluation of $\mathrm{NO}_{\mathrm{x}}$ formation in pulverized coal firing by use of nitrogen isotope ratios. In: ASME 2000 International Joint Power Generation Conference. Miami Beach, FL: American Society of mechanical Engineers, 23-26.

Kirchner M, Jakobi G, Feicht E, et al. 2005. Elevated $\mathrm{NH}_{3}$ and $\mathrm{NO}_{2}$ air concentrations and nitrogen deposition rates in the vicinity of a highway in Southern Bavaria. Atmospheric Environment, 39(25): 4531-4542.

Lin W, Xu X, Ge B, et al. 2011. Gaseous pollutants in Beijing urban area during the heating period 2007-2008: variability, sources, meteorological, and chemical impacts. Atmospheric Chemistry and Physics, 11(15): 8157-8170.

Liu X J, Ju X T, Zhang Y, et al. 2006. Nitrogen deposition in agroecosystems in the Beijing area. Agriculture, Ecosystems \& Environment, 113(1-4): 370-377.

Liu X J, Duan L, Mo J M, et al. 2011. Nitrogen deposition and its ecological impact in China: An overview. Environmental Pollution, 155(10): 2251-2264.

Liu X J, Zhang Y, Han W X, et al. 2013. Enhanced nitrogen deposition over China. Nature, 494(7438): 459-462.

Liu X Y, Xiao H Y, Liu C Q, et al. 2008. Stable carbon and nitrogen isotopes of the moss Haplocladium microphyllum in an urban and a background area (SW China): the role of environmental conditions and atmospheric nitrogen deposition. Atmospheric Environment, 42(21): 5413-5423.

Marttinen S K, Kettunen R H, Sormunen K M, et al. 2002. Screening of physical-chemical methods for removal of organic material, nitrogen and toxicity from low strength landfill leachates. Chemosphere, 46(6): 851-858.

Meng Z Y, Lin W L, Jiang X M, et al. 2011. Characteristics of atmospheric ammonia over Beijing, China. Atmospheric Chemistry and Physics, 11(12): 6139-6151.

Moore H. 1977. The isotopic composition of ammonia, nitrogen dioxide and nitrate in the atmosphere. Atmospheric Environment, 11(12): 1239-1243.

Pan Y P, Wang Y S, Tang G Q, et al. 2012. Wet and dry deposition of atmospheric nitrogen at ten sites in Northern China. Atmospheric Chemistry and Physics, 12(14): 6515-6535.

Perrino C, Catrambone M, Di Menno Di Bucchianico A, et al. 2002. Gaseous ammonia in the urban area of Rome, Italy and its relationship with traffic emissions. Atmospheric Environment, 36(34): 5385-5394.

Proemse B C, Mayer B, Fenn M E, et al. 2013. A multi-isotope approach for estimating industrial contributions to atmospheric nitrogen deposition in the Athabasca oil sands region in Alberta, Canada. Environmental Pollution, 182: 80-91.

Rebolledo B, Gil A, Pallarés J. 2013. A spatial ammonia emission inventory for pig farming. Atmospheric Environment, 64: 125-131.

Reche C, Viana M, Pandolfi M, et al. 2012. Urban $\mathrm{NH}_{3}$ levels and sources in a Mediterranean environment. Atmospheric Environment, 57: 153-164.

Shen J L, Tang A H, Liu X J, et al. 2009. High concentrations and dry deposition of reactive nitrogen species at two sites in the North China Plain. Environmental Pollution, 157(11): 3106-3113.

Sutton M A, Dragosits U, Tang Y S, et al. 2000. Ammonia emissions from non-agricultural sources in the UK. Atmospheric Environment, 34(6): 855-869.

Tang Y S, Cape J N, Sutton M A. 2001. Development and types of passive samplers for monitoring atmospheric $\mathrm{NO}_{2}$ and $\mathrm{NH}_{3}$ concentrations. The Scientific World Journal, 1: 513-529.

Van Der Hoek K W. 1998. Estimating ammonia emission factors in Europe: summary of the work of the UNECE ammonia expert panel. Atmospheric Environment, 32(3): 315-316.

Vranken E, Claes S, Hendriks J, et al. 2004. Intermittent measurements to determine ammonia emissions from livestock buildings. Biosystems Engineering, 88(3): 351-358.

Xiao H Y, Liu C Q. 2002. Sources of nitrogen and sulfur in wet deposition at Guiyang, southwest China. Atmospheric Environment, 36(33): 5121-5130.

Xiao H Y, Tang C G, Xiao H W, et al. 2010. Stable sulphur and nitrogen isotopes of the moss Haplocladium microphyllum at urban, rural and forested sites. Atmospheric Environment, 44(34): 4312-4317.

$\mathrm{Xu}$ W, Zheng K, Liu X J, et al. 2014. Atmospheric $\mathrm{NH}_{3}$ dynamics at a typical pig farm in China and their implications. Atmospheric Pollution Research, 5(3): 455-463.

Zhang Y, Liu X J, Fangmeier A, et al. 2008. Nitrogen inputs and isotopes in precipitation in the North China Plain. Atmospheric Environment, 42(7): 1436-1448. 